Manuscript accepted 21-04-2018 by

International Journal of Logistics: Research \& Applications

\title{
INVESTIGATING EFFECTS OF ORGANIZATIONAL CULTURE AND LEARNING \\ ON ENVIRONMENTAL COLLABORATION AND PERFORMANCE OF KOREAN \\ EXPORTING FIRMS
}

\author{
Hee-Sung Bae \\ Department of International Trade, Kyonggi University \\ Suwon City, Republic of Korea, 16227 \\ hsbae@kyonggi.ac.kr
}

\section{David B. Grant}

Hull University Business School, Hull, United Kingdom, HU5 1DA

Hanken School of Economics, Helsinki, Finland, 00100

d.grant@hull.ac.uk, david.grant@hanken.fi

(corresponding author)

\begin{abstract}
This paper presents an empirical study of the effect of organizational culture and learning capability factors on environmental collaboration and performance in green supply chains. A conceptual model and variables were derived from organizational culture, learning, and collaboration theory and tested with Korean exporting firms. Learning capability was found to positively affect environmental collaboration as staff behavior, attitudes and learning about environmental practices in a focal firm can be increased from suppliers and customers and then disseminated internally. Further, environmental collaboration was found to positively affect environmental performance due to a focal firm sharing these learned capabilities about the environment with other supply chain partners. However, organizational culture was not found to positively affect environmental collaboration. The findings suggest firms can improve environmental capabilities and performance through shared learning with supply chain partners and ensuring they are internally disseminated in the focal organization.
\end{abstract}

Keywords: Organizational Culture, Learning Capability, Environmental Collaboration, Environmental Performance, Exporting Firms

This is an Accepted Manuscript of an article published by Taylor \& Francis in International journal of logistics research and applications on 10 May 2018, available online: https:// www.tandfonline.com/doi/full/10.1080/13675567.2018.1470232. 


\section{Introduction}

Firms would turn threat into opportunity through a strategic approach to environment (Hart, 1995). They perform long-term collaborative environmental management with customers as well as suppliers through green supply chain management and as a result, environmental strategy is regarded as a unique resource because it is useful, rare, difficult to imitate and non-substitutive. This is connected with a sustainable competitive advantage in the market (Bae, 2014; Dierickx and Cool, 1989; Reed and DeFillippi, 1990; Teece, 1987; Winter, 1987). In addition, environmental strategy acts as an entry barrier in the market and it difficultly makes market entries of new entrants (Dean and Brown, 1995). Therefore, firms can create a sustainable competitive advantage in the market through enhancing internal capabilities and change of recognition on natural environment which has a strong regulatory characteristic.

International trade and associated industries account for about $85 \%$ of GDP in the Korean economy (Shin et al., 2017). Environmental regulation may have a role in restricting international trade and of Korean firms in particular if developed countries use it as a trade barrier. In this regard, it would have a direct effect on Korean economy. Korean firms can address any such environmental regulatory problems through environmental collaboration from raw material suppliers to sellers of final goods to mitigate the effects of such regulation and any resulting trade barriers from developed countries and thus maintain competitive advantage.

Prior research verified the positive effect of environmental strategy on environmental performance (Ann et al., 2006; Geffen and Rothenberg, 2000; Giovanni, 2012) and the positive effect of environmental performance on firm performance (Hong et al., 2009; Green et al., 2012). According to the natural resource-based view, to perform environmental strategy, firms should have internal resources which have unique characteristics of resources such as usefulness, rareness, difficulty to imitate and non-substitution and performance is improved when they use the resources. In this regard, the relationship between environmental strategy and environmental performance is explained as exchange theory. The exchange of internal and external information and resources among supply chain partners enhances usability of the information and resources and as a result, performance is increased.

Prior research found various precedent variables to have a positive effect on environmental 
strategy (Chan, 2005; Choi et al. 2017; Green et al., 2012; Haverkamp et al., 2010; Hong et al., 2009; Lee, 2008; Menguc et al., 2010; Rao, 2002; Vachon and Klassen, 2006). These precedent variables reflect internal and external factors of firms from the viewpoint of green supply chain management. Moreover, prior research classified resources of firms into organizational culture and learning capability and verified the effect of them on collaboration (Butler, 2010; Carr and Kaynak, 2007; Rampersad et al., 2010; Sahay et al. 2017; Spekman et al., 2002; Tian et al., 2008; Vieira et al., 2011; Wu et al., 2004). According to the natural resource-based view, organizational culture such as trust, commitment and communication is regarded as internal resources and it has a positive effect on inter-organizational relationships, followed by high performance. In addition, information processing theory explains that learning of managers on external information increases efficiency in internal and external processes of firms and as a result, performance is improved. Therefore, from the viewpoint of green supply chain management, organizational culture and learning capability have a positive effect on environmental collaboration, followed by superior performance.

Despite the causal link between environmental strategy and performance, there are three limitations of the prior research concerned with environmental strategy. The first, research on the relationship between environmental strategy and performance from the viewpoint of exporting firms is needed. Developed countries would use environmental regulations as a trade barrier in the global supply chains. In this regard, Korean exporting firms can find the methods to evade regulations for environment through green supply chain management. Therefore, from the viewpoint of exporting firms, research on the relationship between environmental strategy and environmental performance is directly connected with achieving a competitive advantage.

The second, there is an unclear approach to environmental strategy in the prior research. Some researchers were a strategic approach to environment but the others approach environmental strategy as the viewpoint of pollution prevention and control (Hart and Ahuja, 1996; Russo and Fouts, 1997) and the viewpoint of corporate behavior (Aragon-Correa, 1998; Sharma, 2000). The approach has the viewpoint of excessive control on environment. Therefore, this research will approach environment in a strategic viewpoint.

The third, there are a lack of understanding to precedent variables on environmental 
collaboration. Environmental collaboration in supply chains has a role of connecting capability of firms with competitive advantages (Prahalad and Hamel, 1990; Ulrich and Lake, 1991). Therefore, this research should develop the variables which have a role of leverages on environmental collaboration in supply chains (Hart, 1995). From the viewpoint of the limitations of prior research, the aims of this research are to develop precedent variables to have an effect on environmental collaboration and to analyze the effects of them on environmental performance.

\section{Literature Review}

\section{Organizational culture and environmental collaboration}

Prior research on environmental collaboration in supply chains has classified antecedent variables of environmental collaboration according to external and internal viewpoints. External viewpoints include environment initiative (Rao 2002), supplier green supply chain readiness and buyer green supply chain practices (Lee 2008), and customer environmental sensitivity (Menguc et al. 2010). Internal viewpoints include general and specific organizational capabilities (Chan 2005), logistical and technological integration (Vachon and Klassen 2006) and green information systems (Green et al. 2012). An internal viewpoint which has an influence on environmental collaboration can be approached from the viewpoint of the focal organization.

There is little prior research concerned with the relationship between environmental collaboration and organizational culture. However, in the supply chain management (SCM) literature organizational culture is presented as an important factor to achieve a competitive advantage and is based on collaborative processes among firms in the supply chain, both upstream and downstream, and processes that enable information sharing among firms (Grant 2012). Information sharing thus assists in achieving sustainable competitive advantage in a market through sharing core competences among supply chain partners.

Organizational culture for environmental collaboration is classified into commitment, trust and communication (Barratt 2004). Firms can remove inefficiency and overlap occurring in inter-corporate activities when they increase the degree of commitment for duties among supply chain partners through inter-organizational commitment and as a result, a whole supply chain process can be operated in the most efficiency. In addition, Inter-organizational 
trust is based on collaboration among supply chain partners. Mutual trust among supply chain partners is the cause of acquiring knowledge and skill of partners and the cause of building superior supply chain processes compared with competitors' processes. Moreover, interorganizational communication helps minimize supply chain conflicts through making knowledge possible and sharing information among supply chain partners. In this regard, supply chain partners can determine problems and suggest solutions in the whole supply chain process through mutual communication. Moreover, from the viewpoint of international trade, wholesalers/retailers of developed countries cooperate with manufacturing firms in developing countries to achieve high levels of environmental regulations in their countries, the manufacturing firms should collaborate with oversea suppliers to coincide with customer needs, and they finally attain green supply chain management. To achieve this, supply chain participants need to perform mutual communication, trust and commitment as organizational culture. Therefore, organizational culture is also an enabler of environmental collaboration in supply chains.

Communication, trust and commitment are precedent variables of collaboration in supply chains. Manufacturing firms make manufacturing plans on the basis of selling plans of wholesalers/retainers, and the manufacturing plans are based on supplying plans because it is connected with suppliers. The collaboration is made by communication, performed by mutual trust on information and achieved by mutual commitment on goals in supply chains. This can be applied to environmental collaboration. Therefore, communication, trust and commitment are precedent factors of environmental collaboration.

In addition, the relationship between organizational culture and environmental collaboration can be explained by the transaction cost theory. Firms make collaborative culture such as commitment, trust and communication and as a result, they enhance the level of collaboration among supply chain partners. Firms which have collaborative organizational culture behave commitment, trust and communication with their partners to minimize uncertainty and opportunistic behavior and this is connected with inter-corporate collaborative behavior like environmental collaboration. Therefore, firms which have collaborative culture make collaborative network or quasi-hierarchy (Dunning 1993; Bae 2014) with partners through environmental collaboration to minimize transaction cost in the market. Moreover, the relationship between the variables can be also explained by the institutional theory. 
Commitment, trust and communication as inter-corporate collaborative culture are regarded as the cognitive viewpoint (Scott 1995) and it is encoded and inherent to supply chain participants, followed by collaborative behavior. Collaborative behavior on the basis of collaborative culture is sustained and it is connected with the institution. The collaborative institution is sustained and as a result, it is routine. Therefore, the relationship between organizational culture and environmental collaboration can be explained by the institutional theory.

The relationship between organizational culture and environmental collaboration is explained by a natural resource-based view (Hart, 1995). Organizational culture as the factor to enhance organizational capability is usefully used by firms, it is a rare resource because firms do not easily buy it in the market, competitors are difficult to imitate it and competitors are not able to substitute other resources for it. Organizational culture as the resource has societal complexity and causal ambiguity in the relationship with performance. In this regard, organizational culture as the relationship between firms can be treated with firms' resource and it has a positive effect on environmental collaboration.

Finally, the relationship between organizational culture and environmental collaboration can be explained as information processing theory. If managers acquire capabilities of partners through commitment, trust and communication as organizational culture in supply chains and make supply chain processes to harmonize environmental regulations through applying the capability to internal processes, they can achieve a high level of environmental collaboration. When managers acquire capabilities concerned with environmental collaboration of partners through organizational culture and apply the capabilities to internal processes, they can increase the level of environmental collaboration in the whole supply chain process. Therefore, a relationship between organizational culture and environmental collaboration is proposed as hypothesis 1:

\section{H.1: Organizational culture positively affects environmental collaboration.}

\section{Learning ability and environmental collaboration}

Prior research has not deeply investigated the relationship between learning capability and environmental collaboration. However, there is prior research concerned with the relationship 
between learning capability and supply chain collaboration. In this regard, this research will verify the relationship between learning ability and environmental collaboration through prior research on the relationship between learning ability and supply chain collaboration. From the viewpoint of inter-corporate relationships, organizational learning means that firms share the capabilities among partners in supply chains. This means that firms strategically enhance inter-organizational learning capability through alliance, partnership and collaboration (Engistorm and Kerosus 2007). Therefore, from the viewpoint of an inter-corporate relationship, learning capability means that firms mutually share core competence among supply chain partners.

Learning capability with respect to SCM is defined as the behavior and attitude of firms to increase their capability among partners in their supply chains (Bowen et al. 2001; Hamel 1991; Spekman et al. 2002). Prior research has considered learning capability from various viewpoints, and from an inter-corporate viewpoint is classified as learning encouragement, learning systems and integrative mechanism (ibid.). Also, there is positive effect of learning capability on organizational innovation intensity (Weerawardena 2003), organizational innovation and knowledge management capability (Kuo 2011), financial and non-financial performance (Prieto and Revilla 2006) and organizational performance (Limpibunterg and Johri 2009). The relationship between learning capability and environmental collaboration can thus be posited as processing information. Managers can check the efficacy of their present supply chain processes through learning the capability of their partners and as a result can remove overlaps and/or inefficiencies existing in those processes. Superior capabilities of partners are shared with other partners through in supply chain to increase supply chain efficiency. In this regard, environmental collaboration can be approached from the viewpoint of innovation.

Environmental collaboration therefore includes a firm's internal and external collaborations concerned with the natural environment from the perspective of sharing and efficiency through innovation, and performance is thereby connected with efficiency that is affected collaboration. Learning capability, therefore, is thus considered an antecedent factor of environmental collaboration. This also means that from an internal viewpoint, environmental collaboration is spread to all departments through learning capability and from an external viewpoint, environmental collaboration is disseminated to supply chain partners through 
learning capability. Therefore, the relationship between learning capability and environmental collaboration is proposed as hypothesis 2 :

\section{H.2: Learning capability positively affects environmental collaboration.}

\section{Environmental collaboration and environmental performance}

The relationship between environmental collaboration and environmental performance has been discussed widely in the literature. A positive effect on environmental performance has been found through environmental collaboration (Vachon and Klassen 2008), environmental initiative (Rao 2002), internal management (Shukla et al. 2009), adaption of environmental strategies (Chan 2005), environmental monitoring of suppliers and customers (Green et al. 2012), internal and external environmental management (Giovanni 2012), employee pollution prevention training and pollution prevention for suppliers (Theyel 2000), green marketing strategy (Fraj et al. 2013) and green supply chain management practices (Zhu et al. 2013).

Further, Hong et al. (2009) noted that strategic green orientation has a positive effect on green performance outcomes while Rao and Holt (2005) verified that green inbound, production and outbound activities have a positive effect on competitiveness. Menguc et al. (2010) ascertained the positive effect of proactive environmental strategy on sale growth and profit growth and Menguc and Ozanne (2005) found that a natural environmental orientation has a positive effect on market share and profit. Haverkamp et al. (2010) demonstrated the positive effect of environmental communication and department involvement on environmental management capabilities, and Lopez-Rodriguez (2009) ascertained that organizational functions have a positive effect on greening manufacturing processes. Wu (2013) found a positive effect of green supply chain integration on green innovation while Lee et al. (2013) found that green supply chain practices due to external pressures has a positive effect on supply chain resource requirements and green supply chain practices due to internal pressures has a positive effect on supply chain flexibility.

Prior research verified that various environmental management activities have a positive effect on environmental performance and firm performance. However, there are dimensions in relationships between environmental performance and firm performance. Performance can be classified into strategic, tactical and operational dimension (Gunasekaran et al. 2004; Bae 
et al. 2013). In this regard, environmental performance can be treated with an operational dimension and firm performance can be considered with a strategic dimension. Therefore, this study will verify the effect of environmental collaboration as an operational dimension on environmental performance as an operational dimension because there are different dimensions between environmental performance and firm performance.

Environmental problems are treated in WTO Green Round and represented from the viewpoint of trade barriers. In this regard, environmental problems are emerged into the viewpoint of regulations on the activities of firms. Firms approach environmental problems as a strategic viewpoint as well as a regulatory viewpoint. It is approached to an internal viewpoint of firms in the past but it is recognized as a collaborative viewpoint among supply chain partners in the present. In the future, firms should response to environmental regulations (Hart 1995) and overcome environmental pressure and only the firms can enjoy sustainable competitive advantages in the market (Schmidheiny 1992; Van den Berg 2017). In this regard, environmental collaboration is important to supply chain participants as well as an internal viewpoint.

Environmental collaboration should be managed to the whole viewpoints of supply chains including suppliers, manufacturers and customers. It is started from an internal viewpoint and connected to an external viewpoint including customers and suppliers (Hart 1995). Firms which have a high level of environmental capabilities can make superior green supply chains with suppliers and customers and the capabilities are useful, rare, imperfect to imitate and non-substitute in the market, followed by causal ambiguity and social complexity on the relationship with performance. Therefore, environmental collaboration is a core resource of firms and is based on enhancing performance.

When firms approach environmental problems as a strategic viewpoint in natural resourcebased view, they can escape pressure concerned with environment. In addition, if they use it from the strategic viewpoint, they can achieve sustainable development (2005). Firms approach environmental problems as uncertainty and treating environmental problems from the viewpoint of green supply chain management and a natural resource-based view is based on increasing capabilities of firms and organizational value, followed by superior performance (Banerjee 2001). 
The relationship between environmental management activities and environmental performance can be based on the relationship between environmental collaboration and environmental performance. Environmental collaboration means inter-organizational collaboration for environmental management in supply chains, which is connected with environmental performance. The relationship between environmental collaboration and environmental performance is explained by the natural resource-based view (NRBV) of the firm. Hart (1995) and Hart and Dowell (2011) insist that firms respond to environmental regulations through change of environmental activities in their business processes. However, activities for environmental management are performed with a tendency to make capabilities act as an entry barrier to the market to provide a source of a sustainable competitive advantage.

In this regard, such activities should be approached from the viewpoint of supply chains rather than an internal viewpoint of a firm. Only those firms that achieve standardization and efficiency concerned with environmental management in supply chains should attain superior environmental performance such as reducing air emission, waste water and solid wastes, decreasing consumption of dangerous materials and frequency for environmental accidents and improving environmental situation. These firms thus are performing green supply chain management and as a result enjoy sustainable competitive advantages in the market. Therefore, the relationship between environmental collaboration and environmental performance is proposed as hypothesis 3:

\section{H.3: Environmental collaboration positively affects environmental performance.}

\section{The research model and methods}

\section{Conceptual model}

The objective of this study is to analyze the relationship between determinant factors of environmental collaboration, i.e. organizational culture and learning capability, and environmental performance. The theoretical relationship between the variables discussed above is presented in the conceptual research model shown in Figure 1.

\section{[Figure 1 here]}




\section{Research methods}

The conceptual and operational definitions of the variables were developed from the literature and their content is as follows. First, organizational culture means reliance of staff to achieve common aims and to work with partners in supply chains (Barratt 2004). It is classified into trust, commitment and communication. Commitment is defined as attitude to devote time, energy and support on the relationship between partners in supply chains (Monczka et al. 1998). Trust means predictable behaviors among partners and it is defined as behaviors to have not the negative effect on the partners. Communication means quantity, quality and frequency of information exchange among partners (Hutt et al. 2000; Mohr and Nevin 1990).

Second, learning capability is defined as behavior and attitude of firms to increase learning capability in supply chains (Bowen et al. 2001; Hamel 1991; Spekman et al. 2002). It is classified into learning encouragement, learning systems and integrative mechanism. Learning encouragement means the degree of sharing of ideas and support of operations among partners in supply chains. Learning systems mean the degree of developing, sharing and supporting new ideas in the whole supply chain. Integrative mechanism means the degree of performing management with partners to use information technology in supply chains.

Third, environmental collaboration occurs when firms that have high quality of environmental capabilities disseminate green knowledge to supply chain partners by means of diffusing new capabilities to achieve high efficiency in supply chain processes (Dyer and Singh 1998). It is divided into internal collaboration, supplier collaboration and customer collaboration. Environmental performance means the effectiveness of firms to coincide with social expectations concerned with natural resource (Judge and Douglas 1998) and connected with minimizing environmental pollution. All measurement items are shown in appendix 1 and were tested with respondents with a questionnaire using seven point Likert scale with anchor points of $1=$ strongly disagree and $7=$ strongly agree .

The sample population is Korean exporting firms as this research is analyzing relationships between environmental collaboration and performance of global supply chain firms. Korea made free trade agreement (FTA) with various countries such as US, EU and China, and about $85 \%$ of Korean GDP comes from international trade (Shin et al., 2017). The sample 
frame came from a membership list of the Korea International Trade Association and a random sampling method used to select 1,000 firms from the frame. Respondents were managers in manufacturing facilities such as production managers or quality managers, and are considered informed due to the research reflecting both internal and external collaborations concerned with the environment the sample firms operate in and their ability to ascertain improvement of environmental performance in the collaborations. The sample firms responded to the questionnaire by mail, email, telephone, facsimile or personal visit. The survey took place for three months and 222 questionnaires collected. A net 219 questionnaires, or about a $22 \%$ response rate, were used in the analysis due to completion issues.

The reliability and validity of the data collected in the questionnaire were analyzed by various analytical methods (Hair et al. 2010). First, non-response bias of the data was analyzed by analysis of variance; i.e. the data were divided into four groups in arrival order and if there were no gaps in annual turnover, the number of employees, and types of businesses between the first group and the four groups, it was considered there was no non-response bias issue. The results were good and this means that there was no non-response bias. In addition, common method bias was tested. There were two methods used. One was Harmon's single factor test (Podaskoff et al. 2003), which was tested by eigenvalue and dispersion. The other was the method recommended by Sanchez and Brock (1996), which were fitness indices of the results of confirmatory factor analysis. There were no problems in the results as shown in Table 2, Table 3, Table 4 and Table 6. Second, general characteristics of the respondent firms were ascertained as type of business, annual turnover, and the number of staff concerned with the environment. Third, content validity was tested by prior research, verification by experts and averages of measurement items. Fourth, estimate and purification of data were verified by various methods: confirmation of data when a researcher input the data in SPSS; the basic suppositions for multivariate analysis such as normality, homoscedasticity and linearity; correlation analysis to measure internal consistency of measuring items; Cronbach's alpha, exploratory factor analysis, KMO and Bartlett test, Harmon's single-factor test, confirmatory factor analysis for convergent validity; comparison of average variance extracted with square of correlation coefficients for discriminant validity; and tolerance and MAX-VIF for analyzing multicollinearity among independent variables. Finally, relationships among the variables were estimated by structural equation modeling. SPSS 21.0 and AMOS 21.0 are 
used in the analyses. The results of these analyses follow.

\section{Results of the empirical tests}

\section{General characteristics of the respondent firms}

The general characteristics of the 219 Korean exporting firms that responded to the questionnaire are shown in Table 1. There were various types of businesses represented, annual turnover is from below US 1 billion dollars to over US 50 billion dollars, and the largest group of staff looking after environmental issues is below 5. Therefore, there were various exporting firms from small- and medium-sized firms to large-scale firms responding to the questionnaire which we consider gave us a fairly diverse sample.

\section{[Table 1 here]}

\section{The results of reliability and validity analyses}

Before testing the hypotheses we ascertained the reliability and validity of the collected data. The results of the exploratory and confirmatory factor analyses on organizational culture, learning capability, environmental collaboration and environmental performance are shown in Tables 2-4. According to Table 2 there is no problem with the results of the exploratory factor analysis for organizational culture as all statistical results are within prescribed guidelines (Hair et al. 2010). However, the second-order construct communication, which formed part of the organizational culture set along with commitment and trust, had a factor loading coefficient below 0.6 and was therefore deleted. The other items all show over 0.6 in factor loading coefficients, over 1.0 in eigenvalue and below $50 \%$ in percentage of variance. Cronbach's alpha coefficients are over 0.6 and thus we consider there are no problems with the reliability of the data.

\section{[Table 2 here]}

There are also no problems with the results of the confirmatory factor analysis. The items all show over 0.6 in factor loading coefficients, over 0.5 in AVE and over 1.96 in critical ratio. However, the chi-square analysis adopts an alternative hypothesis and this suggests that the characteristics of the sample are not equal to the characteristics of the population. According to Baumgartner and Homburg (1996) if there are over 200 responses the results of a chi- 
square analysis is treated not as a measuring index but as a reference. There are no problems in the results of goodness of fit excluding the result of the chi-square. Therefore, we consider there are no problems in the reliability and validity of commitment and trust for organizational culture.

According to Table 3, there were again no problems in reliability and validity of the measurement items for learning capability. All indices correspond to the criteria but the chisquare analysis again adopts an alternative hypothesis. However, we similarly treat the chi square as a reference in this case. Therefore, we consider there are no problems in the reliability and validity of measurement items for learning capability.

\section{[Table 3 here]}

According to Table 4, there are no problems in the reliability and validity of measurement items for environmental collaboration and performance other than the chi-square as above. Therefore, we consider there are no problems in the reliability and validity of measurement items for environmental collaboration and environmental performance.

\section{[Table 4 here]}

According to the correlation analysis in Table 5, the relationships between all variables are significant at the $\mathrm{p}<0.01$ level. This can be explained as two meanings: one is that independent variables explain a dependent variable very well and the other is that there is a doubt of multicollinearity among the independent variables. The latter can be resolved as the analyses of tolerance $(>0.1)$ and MAX-VIF $(<10.0)$. The results show values for commitment (tolerance $=0.245$ and MAX-VIF $=4.075$, trust $(0.219 ; 4.556$ ), learning encouragement $(0.300 ; 3.333)$, learning systems $(0.333 ; 3.001)$, integrative mechanism $(0.357$; $2.798)$, internal collaboration $(0.288 ; 3.474)$, supplier collaboration $(0.244 ; 4.098)$ and customer collaboration $(0.273 ; 3.663)$. All are within the criteria outlined and hence there are no problems with multicollinearity. In addition, there is no problem with discriminant validity as AVE is higher than square of the correlation coefficients (Hair et al. 2010).

\section{[Table 5 here]}




\section{The result of the hypotheses tests}

The structural relations between the variables were analyzed by structural equation modeling and the results are shown in Table 6. The results show that organizational culture has no effect on environmental collaboration (H.1 unsupported). On the other hand, the results show that learning capability has a positive influence on environmental collaboration (H.2 supported). In addition, the results show that environmental collaboration has a positive influence on environmental performance (H.3 supported). A discussion of these analytical results follows.

\section{[Table 6 here]}

\section{Discussion}

The results of empirical tests are discussed as follows. First, one of the aims of this research is to find the antecedent variables of environmental collaboration. This research suggests organizational culture and learning capability as antecedent variables of environmental collaboration. However, organizational culture of Korean exporting firms is regarded as the step of recognition concerned with environmental management. From this viewpoint, there is no causal relation between organizational culture and environmental collaboration. In addition, organizational culture means reliance of staff to achieve common aims and to work with partners in supply chains (Barratt 2004). It is achieved by commitment, trust and communication. However, it appears that Korean exporting firms have a low level of recognition on green supply chain management and if they have the recognition, it is possible that the level is not high like independent operation or internal collaboration (Bae 2012). Therefore, this research did not verify the positive effect of organizational culture on environmental collaboration.

Moreover, commitment, trust and communication are concerned with the inter-corporate relationships. The sample firms are Korean exporting firms and they are usually export their goods to overseas customers. In this regard, their involvement on customer is not high (Hymer, 1968). That is why the hypothesis is rejected and the research on sub-dimensions of the variables is requested. 
Second, the results show that learning capability is an antecedent variable of environmental collaboration. Learning capability is behavior and attitude of firms to increase capability among partners in supply chains (Hamel, 1991; Spekman et al., 2002). The behavior and attitude on environmental management make possible green supply chain management because the behavior and attitude are shared with suppliers and customers in supply chains as well as being internally disseminated in a firm. The relationship between learning capability and environmental collaboration can be explained as the viewpoint of knowledge management. Firms which have superior capability through learning share their capability with partners in supply chains and as a result, it is possible for them to perform green supply chain management. Superior capability of firms in supply chains is learned and disseminated to their partners and as a result, whole supply chain efficiency is achieved. From this viewpoint, the relationship between learning capability and environmental collaboration can also be explained as the viewpoint of market orientation explained as intelligence generation, intelligence dissemination and responsiveness. Similarly, Korean exporting firms make strategy through analyzing environment in the market. The environmental variance is come from their customers and this is based on amending their internal processes to follow customer needs. Therefore, Korean exporting firms share environmental knowledge with supply chain partners through enhancing learning capability and as a result, perform green supply chain collaboration.

Third, this research verified that environmental collaboration has a positive effect on environmental performance. Environmental collaboration makes possible green supply chain management through sharing the capabilities concerned with environment with supply chain partners. Korean exporting firms share the capabilities with supply chain partners through environmental collaboration. Environmental collaboration makes possible whole green supply chain management from suppliers to manufacturers and wholesaler/retailor. The green supply chain management is connected with superior environmental performance. The relationship between environmental collaboration and environmental performance can be explained as natural resource-based view. Environmental collaboration can be explained as the inter-corporate viewpoint as well as the internal viewpoint of a firm. Environmental collaboration is the capability of firms which is useful, rare, difficult to imitate and nonsubstitutive and has causal ambiguity and social complexity on the relationship with performance. Therefore, the capability of Korean exporting firms concerned with 
environmental collaboration is the cause of achieving superior environmental performance because it has a role of barriers to entry for new entrants and produces the monopolistic advantage compared with competitors in the market. Prior research posited a positive relationship between environmental management and environmental performance (Rao 2002; Fraj et al. 2013) and suggested this relationship could also be explained by a natural resourcebased view (Hart 1995; Hart and Dowell 2011).

\section{Conclusions}

To achieve the aims of this research, prior research was based on the theoretical relationships between the variables and this research developed the conceptual and operational definitions of the variables. Data for the analysis were collected by a survey. The population is Korean exporting firms and the sample frame is a membership list of the Korea International Trade Association. A survey was performed to the sample firms and 219 data were collected. The collected data were verified with reliability and validity and the causal relationships between the variables were analyzed. The theoretical implications were discussed and managerial implications, limitations and future research directions are as follows.

There are two contributory managerial implications. First, learning capability is regarded as the effort of learning superior capability among partners in supply chains. Environmental management should be approached as the viewpoint of supply chain management and for environmental collaboration, managers should encourage staff who shares superior operational systems and ideas of partners. In addition, managers stimulate staff who develop new ideas with partners and they should perform management with partners to use information systems. In this regard, managers can acquire eco-friendly knowledge of partners. This is connected with high efficiency in supply chain processes. Therefore, managers enhance learning capability of staff in supply chains and as a result, green knowledge is shared, followed by green supply chain management.

Second, Korean exporting firms disseminate environmental knowledge among departments in the internal viewpoint and share environmental knowledge with suppliers and customers in the external viewpoint. For this reason, managers should increase staff's interest in environmental collaboration and they should share environmental knowledge through communication with partners. As a result, Korean exporting firms can decrease pollution, 
waste, consumption for hazardous/harmful/toxic materials and frequency for environmental accidents and improve an enterprise's environmental situation. Therefore, managers can achieve superior environmental performance through environmental collaboration.

However, as with all research studies there are a few limitations. First, no effect of organizational culture on environmental collaboration was found. In this research we consider the reason that Korean exporting firms have low levels of recognition of environmental management is that the recognition is connected with a low level of organizational culture concerned with environmental management. We consider that managers need to enhance their organizational culture through enhancing their recognition on environmental management and green supply chain management, and future research should investigate that issue more deeply. In addition, researchers need to investigate the role of organizational culture on the relationship between environmental collaboration and environmental performance. Second, the chi-square and degrees of freedom analysis adopted an alternative hypothesis in the result for goodness of fit. This means that the result of this research can only be applied to the sample firms. Future research in this area will need to collect sufficient data as the coefficient of chi-square responds sensitively to the number of respondents.

\section{References}

Ann, G.E., S. Zailani and N.A. Wahid (2006), "A Study on the Impact of Environmental Management System (EMS) Certification towards Firms' Performance in Malaysia”, Management of Environmental Quality: An International Journal, Vol. 17, No. 1, pp. 73-93.

Aragon-Correa, J.A. (1998), "Strategic Proactivity and Firm Approach to the Natural Environment", Academy of Management Journal, Vol. 41, No. 5, pp. 556-567.

Bae, H.S. (2012), “An Analysis of Gaps in Performance among Development Stages of Integration in SCM", Journal of International Logistics and Trade, Vol. 10, No. 3, pp. 85-104.

Bae, H.S. (2014), Investigating the Effect of Environmental Uncertainty on Supply Chain Collaboration and Operational Performance, Ph.D. Dissertation, University of Hull.

Bae, H.S., W.Y. Lee and Y.K. Lee (2013), "The Effect of Customer Service on Firm Performance: Developing Scales for Performance Measurement of Customs Clearance Firms", Journal of International Logistics and Trade, Vol. 11, No. 2, pp. 47-70.

Bae, H.S. (2014), Investigating the Effect of Environmental Uncertainty on Supply Chain Collaboration and Operational Performance, Ph.D. dissertation, the University of Hull.

Barratt, M. (2004), "Understanding the Meaning of Collaboration in the Supply Chain", Supply Chain Management: An International Journal, Vol. 9, No. 1, pp. 30-42.

Baumgartner, H. and C. Homburg (1996), “Applications of Structural Equation Modeling in 
Marketing and Customer Research: A Review", International Journal of Research in Marketing, Vol. 13, No. 2, pp. 139-161.

Bowen, F.E., P.D. Cousins, R.C. Lamming and A.C. Faruk (2001), "The Role of Supply Management Capabilities in Green Supply", Production and Operations Management, Vol. 10, No. 2, pp.174-189.

Butler, C.J. (2010), "Internal and Lateral Communication in Strategic Alliance Decision Making”, Management Decision, Vol. 48, NO. 5, pp. 698-712.

Cao, X. and Quazi, A. (2017), "Does an Institutional Factor Influence Corporate Environmental Strategy? Looking through the Guanxi Lens", Sustainability Accounting, Management and Policy Journal, Vol. 8, No. 1, pp.

Carr, A.S. and H. Kaynak (2007), "Communication Methods, Information Sharing, Supplier Development and Performance: An Empirical Study of Their Relationships", International Journal of Operations and Production Management, Vol. 27, No. 4, pp. 346-370.

Chan, R.Y.K. (2005), "Does the Natural-Resource-Based View of the Firm Apply in an Emerging Economy? A Survey of Foreign Invested Enterprises in China", Journal of Management Studies, Vol. 42, No. 3, pp. 625-672.

Choi, S.B., Min, H., Joo, H.Y. and Choi, H.B. (2017), “Assessing the Impact of Green Supply Chain Practices on Firm Performance in the Korean Manufacturing Industry", International Journal of Logistics, Vol. 20, No. 2, pp., 129-145.

Dean, T.J. and R.L. Brown (1995), "Pollution Regulation as a Barrier to new Firm Entry: Initial Evidence and Implications for Future Research", Academy of Management Journal, Vol. 38, pp.288-303.

Dierickx, I. and K. Cool (1989), "Asset Stock Accumulation and Sustainability of Competitive Advantage”, Management Science, Vol. 35, pp. 1504-1511.

Dyer, J.H. and H. Singh (1998), "The Relational View: Cooperative Strategy and Sources of Interorganizational Competitive Advantage", Academy of Management Review, Vol. 23, No. 4, pp. 660-679.

Engestrom, Y. and H. Kerosuo (2007), "From Workplace Learning to Inter-organizational Learning and Back: the Contribution of Activity Theory", Journal of Workplace Learning, Vol. 19, No. 6, pp. 336-342.

Fraj, E., E. Martinez and J. Matute (2013), "Green Marketing in B2B Organisations: An Empirical Analysis from the Natural-Resource-based View of the Firm", Journal of Business and Industrial Marketing, Vol. 28, No. 5, pp. 396-410.

Geffen, C. and S. Rothenberg (2000), "Sustainable development across firm boundaries: The Critical Role of Suppliers in Environmental Innovation", International Journal of Operations and Production Management, Vol. 20, No. 2, pp. 166-186.

Giovanni, P.D. (2012), "Do Internal and External Environmental Management Contribution to the Triple Botton Line?", International Journal of Operations and Productional Management, Vol. 32, No. 3, pp. 265-290.

Grant, D.B. (2012), Logistics Management, London: Pearson Education.

Grant, D.B., Trautrims, A. and Wong, C.Y. (2015), Sustainable Logistics and Supply Chain Management (Revised ed.), London: Kogan Page.

Green, K.W., P.J. Zelbst, V.S. Bhadawria and J. Meacham (2012), “Do Environmental Collaboration and Monitoring enhance Organizational Performance?" Industrial Management and Data Systems, Vol. 112, No. 2, pp. 186-205.

Gunasekaran, A.C., C. Patel and E. Mcgaughey (2004), "A Framework for Supply Chain Performance Measurement", International Journal of Operations and Production Management, Vol. 21, No. 1/2, pp. 71-87. 
Hamel, G. (1991), “Competition for Competence and Inter-partner Learning within International Strategic Alliances", Strategic Management Journal, Vol. 12, pp. 83103.

Hair, J.F., W.C. Black, B.J. Babin and R.E. Anderson (2010) Multivariate Data Analysis: A Global Perspective, New Jersey: Pearson Education Inc.

Hart, S.L. (1995), “A Natural-Resource-based View of the Firm”, Academy of Management Review, Vol. 20, No. 4, pp.986-1014.

Hart, S.L. and G. Ahuja (1996), "Does It Pay to be Green? An Empirical Examination of the Relationship between Emission Reduction and Firm Performance", Business Strategy and the Environment, Vol. 5, pp. 30-37.

Hart, S.L. and Dowell, (2011), "A Natural-resource-based View of the Firm: Fifteen Years After", Journal of Management, Vol. 37, No. 5, pp. 1464-1479.

Haverkamp, D.-J., H. Bremmers and O. Omta (2010), "Stimulating Environmental Management Performance: towards a Contingency Approach", British Food Journal, Vol. 112, No. 11, pp. 1237-1251.

Hong, P., H.B. Kwon and J.J. Roh (2009), "Implementation of Strategic Green Orientation in Supply”, European Journal of Innovation Management, Vol. 12 No. 4, pp. 512-532.

Hutt, M.D., E.R. Stafford, B.A. Walker and P.H. Reingen (2000), "Case Study: Defining the Social Network of a Strategic Alliance", Sloan Management Review, pp. 51-62.

Hymer, S.H. (1968), "The Large Multinational Corporation: An Analysis of Some Motives for the International Integration of Business", Revue Economique, Vol. 19, No. 5, pp. 8-29.

Judge, W.Q. and T.J. Douglas (1998), "Performance Implications of Incorporating Natural Environmental Issues into the Strategic Planning Process: An Empirical Assessment", Journal of Management Studies, Vol. 35, No. 2, pp. 241-262.

Kuo, T.-H. (2011), "How to improve Organizational Performance through Learning and Knowledge?", International Journal of Manpower, Vol. 32, No. 5, pp. 581-603.

Lee, S.Y. (2008), "Drivers for the Participation of Small and Medium-sized Suppliers in Green Supply Chain Initiatives", Supply chain Management: An International Journal, Vol. 13, No. 3, pp. 185-198.

Lee, S.M., J.S. Rha, D. Choi and Y. Noh (2013), "Pressures Affecting Green Supply Chain Performance", Management Decision, Vol. 51, No. 8, pp. 1753-1768.

Limpibunterng, T. and L.M. Johri (2009), "Complementary Role of Organizational Learning Capability in New Service Development (NSD) Process", The Learning Organization, Vol. 16, No. 4, pp. 326-348.

Lopez-Rodriguez, S. (2009), "Environmental Engagement, Organizational Capability and Firm Performance”, Corporate Governance, Vol. 9, NO. 4, pp. 400-408.

Menguc, B. and L.K. Ozanne (2005), "Challenges of the Green Imperative: A Natural Resource-Based Approach to the Environmental Orientation-Business Performance Relationship", Journal of Business Research, Vol. 58, pp. 430-438.

Menguc, B., S. Auh and L. Ozanne (2010), "The Interactive Effect of Internal and External Factors on a Proactive Environmental Strategy and its Influence on a Firm's Performance", Journal of Business Ethics, Vol. 94, pp. 279-298.

Monczka, R.M., K.J. Petersen, R.B. Handfield and G.L. Ragatz (1998), "Success Factors in Strategic Supplier Alliances: The Buying Company Perspective”, Decision Science, Vol. 29, No. 3, pp. 553-577.

Mohr, J. and J.R. Nevin (1990), "Communication Strategies in Marketing Channels: A Theoretical Perspective", Journal of Marketing, Vol. 54, pp. 36-51.

Podsakoff, P.M., S.B. Mackenzie, J.Y. Lee and N.P. Podsakoff (20030, “Common Method 
Bias in Behavioral Research: A Critical Review of the literature and Recommended Remedies", Journal of Applied Psychology, Vol. 88, No. 5, pp. 879-903.

Prahalad, C.K. and G. Hamel (1990), "The Core Competence of the Corporation", Harvard Business Review, Vol. 68, No. 3, pp. 79-91.

Prieto, I.M. and E. Revilla (2006), "Learning Capability and Business Performance: A Nonfinancial and Financial Assessment”, The Learning Organization, Vol. 13, No. 2, pp. 166-185.

Rahim,, R.E.A. and Rahman, A.A. (2013), "Applicability of Resource-based Environmental Studies in Green IT”, Journal of Systems and Information Technology, Vol. 15, No. 3, pp. 269-286.

Rampersad, G., P. Quester and I. Tooshani (2010), "Examining Network Factors:

Commitment, Trust, Coordination and Harmony", Journal of Business and Industrial Marketing, Vol. 25, No. 7, pp. 487-500.

Rao, P. (2002), "Greening the Supply Chain: A New Initiative in South East Asia", International Journal of Operations and Production Management, Vol. 22, No. 6, pp. 632-655.

Rao, P. and D. Holt (2005), "Do Green Supply Chains lead to Competitiveness and Economic Performance?", International Journal of Operations and Production Management, Vol. 25, No. 9, pp. 898-916.

Reed, R. and R. DeFillippi (1990), "Causal Ambiguity, Barriers to Imitation, and Sustainable Competitive Advantage", Academy of Management Review, Vol. 15, pp.88-102.

Russo, M.V. and P.A. Fouts (1997), "A Resources-based Perspective on Corporate

Environmental Performance and Profitability", Academy of Management Journal, Vol. 40, No. 3, pp. 534-559.

Sahay, B.S., Shankar, R. and Sarma, P.R.S. (2017), "Supply Chain Agility: Review, Classification and Synthesis", International Journal of Logistics, Vol. 20, No. 6, pp., 532-559.

Sanchez, J.I. and P. Brock (1996), "Outcomes of Perceived Discrimination among Hispanic Employees: is Diversity Management a Luxury or a Necessary?", Academy of Management Journal, Vol. 39, No. 3, pp. 704-719.

Schmidheiny, S. (1992), Changing Course: a Global Business Perspective on Development and the Environment, Cambridge (MA): MIT Press.

Sharma, S. (2000), "Managerial Interpretations and Organizational Context as Predictors of Corporate Choice of Environmental Strategy", Academy of Management Journal, Vol. 681-697.

Shin, S.Y., E.S. Lee and D.H. Kim (2017), “A Study on Demand Estimation on Korean Forwarders of Oversea Korean International Trading Firms, Korean Maritime Institute, Present Issue 2017-04, pp. 1-70.

Shukla, A.C., S.G. Deshmukh and A. Kanda (2009), "Environmentally Responsive Supply Chains", Journal of Advances in Management Research, Vol. 6, No. 2, pp. 154-171.

Spekman, R.E., J.S. Spear and J. Kamauff (2002), "Supply Chain Competency: Learning as a Key Component", Supply Chain Management: An International Journal, Vol. 7, No. 1, pp. 41-55.

Teece, D.J. (1987), "Profiting from Technological Innovation: Implications for Integration, Collaboration, Licensing, and Public Policy”, In D.J. Teece (Ed.) The Competitive Challenge, Cambridge, MA: Ballinger, pp. 185-220.

Theyel, G. (2000), "Management Practices for Environmental Innovation and Performance", International Journal of Operations and Production Management, Vol. 20, No. 2, pp. 249-266. 
Tian, Y., F. Lai and F. Daniel (2008), "An Examination of the Nature of Trust in Logistics Outsourcing Relationship: Empirical Evidence from China”, Industrial Management and Data Systems, Vol. 108, No. 3, pp. 346-367.

Ulrich, D. and D. Lake (1991), Organizational Capability, New York: Wiley.

Vachon, S. and R.D. Klassen (2006), "Extending Green Practices across the Supply Chain", International Journal of Operations and Production Management, Vol. 26, No. 7, pp. 795-821.

Vachon, S. and R.D. Klassen (2008), "Environmental Management and Manufacturing Performance: The Role of Collaboration in the Supply Chain", International Journal of Production Economics, Vol. 111, No. 2, pp. 299-315.

Van den Berg, R. (2017), "Environmental Sustainability in Container Transport: The Attitudes of Shippers and Forwarders", International Journal of Logistics, Vol. 20, No. 2, pp., 146-162.

Vieira, V.A., P.R. Monteriro and R.T. Veiga (2011), "Relationship Marketing in Supply Chain: An Empirical Analysis in the Brazilian Service Sector", Journal of Business and Industrial Marketing, Vol. 26, No. 7, pp. 524-531.

Weerawardena, J. (2003), "Exploring the Role of Market Learning Capability in Competitive Strategy", European Journal of Marketing, Vol. 37, No. 3, pp. 407-429.

Winter, S. (1987), "Knowledge and Competence as Strategic Assets", In D. Teece (Ed.), The Competitive Challenge, Cambridge, MA: Ballinger, pp. 159-184.

Wu, W.-Y., C.-Y. Chiag, Y.-J. Wu and H.-J. Tu (2004), "The Influence Factors of Commitment and Business Integration on Supply Chain Management", Industrial Management and Data Systems, Vol. 104, No. 4, pp. 322-333.

Wu, G-C. (2013), "The Influence of Green Supply Chain Integration and Environmental Uncertainty on Green Innovation in Taiwan's IT Industry", Supply Chain Management: An International Journal, Vol. 18, No. 5, pp. 539-552.

Zhu, Q., J. Sarkis and K-H. Lai(2013), "Institutional-based Antecedents and Performance Outcomes of Internal and External Green Supply chain Management Practices", Journal of Purchasing and Supply Management, Vol. 19, No. 2, pp. 106-117. 


\section{Appendix 1. Measurement items and sources}

\begin{tabular}{|c|c|c|}
\hline Variables & Items & Sources \\
\hline Commitment & $\begin{array}{l}\text { This partner is committed to us (OC 1). } \\
\text { We are willing to devote extra effort to sustaining this relationship (OC 2). } \\
\text { Maintaining this relationship is vital (OC 3) } \\
\text { Sustaining this relationship is important (OC 4) } \\
\text { This partner is willing to devote energy to sustain the relationship (OC 5) }\end{array}$ & \multirow[t]{3}{*}{$\begin{array}{l}\text { Monczka et } \\
\text { al., 1998; } \\
\text { Barratt et al., } \\
2004\end{array}$} \\
\hline Trust & $\begin{array}{l}\text { This partner is trustworthy (OC 6). } \\
\text { We have complete confidence in this partner's motives (OC 7). } \\
\text { We have faith in this partner (OC 8). } \\
\text { We have a high level of trust within this supply chain (OC 9). }\end{array}$ & \\
\hline Communication & $\begin{array}{l}\text { Frequent communication occurs between the firms (OC 10). } \\
\text { There is continuous contact between our firm and this partner (OC 11). } \\
\text { Communication between our organization and this partner is frequent (OC } \\
\text { 12). } \\
\text { There is a high level of contact between our firm and this partner (OC 13). }\end{array}$ & \\
\hline $\begin{array}{l}\text { Learning } \\
\text { encouragement }\end{array}$ & $\begin{array}{l}\text { Different points of view are encouraged within this supply chain (LA 1). } \\
\text { Developing new insights is important to our supply chain (LA 2). } \\
\text { Members of this supply chain develop many new insights (LA 3). } \\
\text { New ideas are generally accepted by members of this supply chain (lea 4). } \\
\text { This supply chain supports experimentation (LA 5). } \\
\text { Generating new ideas is widespread throughout this supply chain (LA 6). }\end{array}$ & \multirow[t]{3}{*}{$\begin{array}{l}\text { Hamel, 1991; } \\
\text { Spekman et } \\
\text { al., } 2002\end{array}$} \\
\hline $\begin{array}{l}\text { Learning } \\
\text { systems }\end{array}$ & $\begin{array}{l}\text { The systems and procedures of this supply chain support innovation } \\
\text { transfer between supply chain members (LA 7). } \\
\text { This supply chain structure supports the development of new ideas (LA 8). } \\
\text { This supply chain structure facilitates the sharing of ideas between } \\
\text { members (LA 9). } \\
\text { This supply chain rewards new ideas (LA 10). } \\
\text { Within the supply chain, we are rewarded for sharing our ideas with our } \\
\text { supply chain partners (LA 11). }\end{array}$ & \\
\hline $\begin{array}{l}\text { Integrative } \\
\text { mechanism }\end{array}$ & $\begin{array}{l}\text { Concerned with extent of use within supply chains, electronic data } \\
\text { interchange (EDI) links (LA 12). } \\
\text { Integrated business systems (LA 13) } \\
\text { Partner as operational part of supply/demand planning (LA 14) } \\
\text { IT integration with all suppliers/customers (LA 15) } \\
\text { Partner personnel involved in product design (LA 16) }\end{array}$ & \\
\hline $\begin{array}{l}\text { Internal } \\
\text { collaboration }\end{array}$ & $\begin{array}{l}\text { Liaison between purchasing and other functions (GC 1) } \\
\text { Detailed purchasing policies and procedures (GC 2) } \\
\text { Partnership approach with suppliers (GC 3) } \\
\text { Technical skills of purchasing professionals (GC 4) } \\
\text { Advanced understanding of environmental issues (GC 5) } \\
\text { The effect of the issues on supply (GC 6) }\end{array}$ & \multirow[t]{3}{*}{$\begin{array}{l}\text { Bowen et al., } \\
\text { 2001; Vachon } \\
\text { and Klassen, } \\
\text { 2006, 2008; } \\
\text { Bae, } 2014\end{array}$} \\
\hline $\begin{array}{l}\text { Supplier } \\
\text { collaboration }\end{array}$ & $\begin{array}{l}\text { Achieving environmental goals collectively (GC 7) } \\
\text { Developing a mutual understanding of responsibilities regarding } \\
\text { environmental performance (GC 8) } \\
\text { Working together to reduce environmental impact of our activities (GC 9) } \\
\text { Conducting joint planning to anticipate and resolve environmental-related } \\
\text { problems (GC 10) } \\
\text { Making joint decisions about ways to reduce overall environmental impact } \\
\text { of our products (GC 11) }\end{array}$ & \\
\hline $\begin{array}{l}\text { Customer } \\
\text { collaboration }\end{array}$ & $\begin{array}{l}\text { Closely contact with customers for environmental collaboration (GC 12) } \\
\text { Consideration of the effect to environment when goods are transported to } \\
\text { customers (GC 13) } \\
\text { Information sharing concerned with environment with customers (GC 14) } \\
\text { Flexible communication concerned with environment with customers (GC }\end{array}$ & \\
\hline
\end{tabular}




\begin{tabular}{|l|l|l|}
\hline & $\begin{array}{l}15) \\
\text { Reflecting requirement of customers concerned with environment in goods } \\
\text { and services (GC 16) }\end{array}$ & \\
\hline $\begin{array}{l}\text { Environmental } \\
\text { performance }\end{array}$ & $\begin{array}{l}\text { Reduction of air emission (EP 1) } \\
\text { Reduction of waste water (EP 2) } \\
\text { Reduction of solid wastes (EP 3) } \\
\text { Decrease of consumption for hazardous/harmful/toxic materials (EP 4) } \\
\text { Decrease of frequency for environmental accidents (EP 5) } \\
\text { Improving an enterprise's environmental situation (EP 6) }\end{array}$ & Zhan, 2005; \\
\hline
\end{tabular}




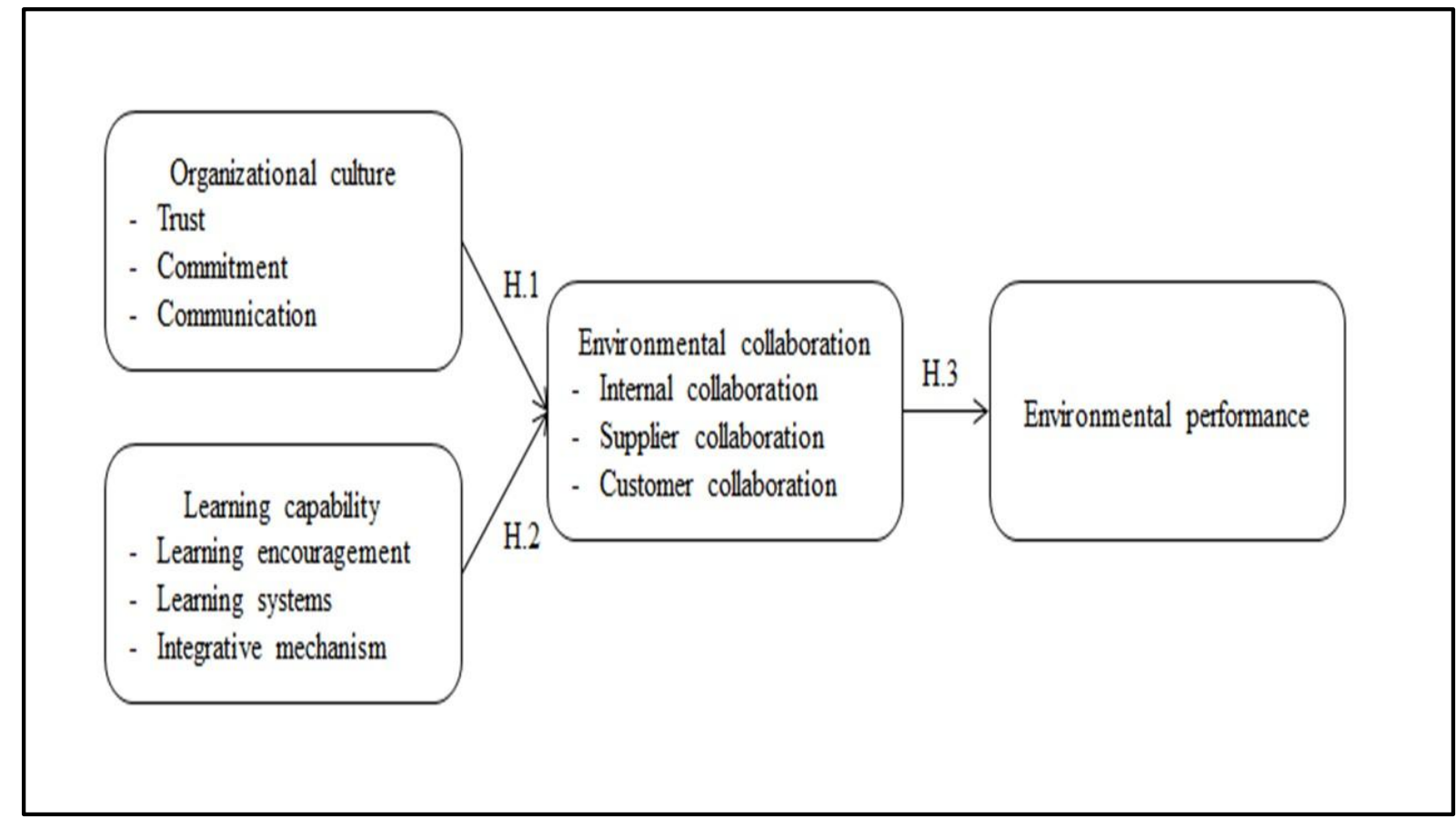

Figure 1: Conceptual Model 
Table 1 General characteristics of the responding firms

\begin{tabular}{|l|l|l|l|}
\hline Type of business & Frequency (\%) & Annual turnover (\$bn) & Frequency (\%) \\
\hline & & Below 1 & $13(5.9)$ \\
Chemistry and Rubber & $19(8.6)$ & $1-5$ & $28(12.8)$ \\
Electricity and Electronics & $22(10.1)$ & $5-10$ & $26(11.9)$ \\
Metal and Non-Metal & $34(15.5)$ & $10-50$ & $37(16.9)$ \\
Machine, Transport and Equipment & $29(13.2)$ & Over 50 & $40(18.3)$ \\
Fiber, Cloth and Leather & $22(10.1)$ & Non-responding & $75(34.2)$ \\
Wood, Paper and Furniture & $10(4.6)$ & & \\
Beverage & $7(3.2)$ & Staff for environment & Frequency (\%) \\
The others & $28(12.8)$ & Below 5 & $86(39.3)$ \\
Non-responding & $48(21.9)$ & $5-10$ & $26(11.9)$ \\
Total & 219 & Over 10 & $27(12.3)$ \\
& \multicolumn{2}{|l}{ Non-responding } & $80(36.5)$ \\
\hline
\end{tabular}


Table 2 Reliability and validity of organizational culture

\begin{tabular}{|c|c|c|c|c|c|c|c|}
\hline \multirow[b]{2}{*}{ Items } & \multicolumn{3}{|c|}{ EFA results } & \multicolumn{4}{|c|}{ CFA results } \\
\hline & $\begin{array}{l}\text { Factor } \\
\text { loading }\end{array}$ & $\begin{array}{l}\text { Reliability } \\
\& \text { validity }\end{array}$ & $\begin{array}{l}\text { Bartlett \& } \\
\text { KMO }\end{array}$ & $\begin{array}{l}\text { Factor } \\
\text { loading }\end{array}$ & AVE & C.R. & Goodness of fit \\
\hline $\begin{array}{l}\text { OC } 1 \\
\text { OC } 2 \\
\text { OC } 3 \\
\text { OC } 4 \\
\text { OC } 5\end{array}$ & $\begin{array}{l}0.766 \\
0.811 \\
0.800 \\
0.813 \\
0.612\end{array}$ & $\begin{array}{l}C: 0.942 \\
E: 4.445 \\
V: 34.194\end{array}$ & \multirow{2}{*}{$\begin{array}{l}\mathrm{KMO}= \\
0.951 \\
\text { Bartlett } \\
\text { test } \\
\mathrm{Chi}= \\
3095.756 \\
\mathrm{df}=78 \\
\mathrm{p}=0.000\end{array}$} & $\begin{array}{l}0.818 \\
0.903 \\
0.939 \\
0.894 \\
0.800\end{array}$ & 0.761 & $\begin{array}{l}13.949^{\text {**** }} \\
16.142^{\text {*** }} \\
17.119^{\text {*** }} \\
15.888^{\text {*** }} \\
-\end{array}$ & \multirow{2}{*}{$\begin{array}{l}\mathrm{Chi}=72.683 \\
\mathrm{df}=25 \\
\mathrm{P}=0.000 \\
\mathrm{Q}=2.907 \\
\mathrm{GFI}=0.931 \\
\mathrm{AGFI}=0.876 \\
\mathrm{CFI}=0.979 \\
\mathrm{RMSEA}= \\
0.094\end{array}$} \\
\hline $\begin{array}{l}\text { OC } 6 \\
\text { OC } 7 \\
\text { OC } 8 \\
\text { OC } 9\end{array}$ & $\begin{array}{l}0.716 \\
0.739 \\
0.727 \\
0.775\end{array}$ & $\begin{array}{l}\text { C: } 0.949 \\
\text { E: } 4.945 \\
\text { V: } 38.040\end{array}$ & & $\begin{array}{l}0.900 \\
0.947 \\
0.916 \\
0.868\end{array}$ & 0.825 & $\begin{array}{l}19.126^{\text {**** }} \\
21.417^{* * * *} \\
19.883^{\text {**** }} \\
-\end{array}$ & \\
\hline
\end{tabular}

Notes) C: Cronbach's alpha, E: eigenvalue, V: percentage of variance; ${ }^{* * *}: \mathrm{p}<0.01$ 
Table 3: Reliability and validity of learning capability

\begin{tabular}{|c|c|c|c|c|c|c|c|}
\hline \multirow[b]{2}{*}{ Items } & \multicolumn{3}{|c|}{ EFA results } & \multicolumn{4}{|c|}{ CFA results } \\
\hline & $\begin{array}{l}\text { Factor } \\
\text { loading }\end{array}$ & $\begin{array}{l}\text { Reliability } \\
\& \text { validity }\end{array}$ & $\begin{array}{l}\text { Bartlett \& } \\
\text { KMO }\end{array}$ & $\begin{array}{l}\text { Factor } \\
\text { loading }\end{array}$ & AVE & C.R. & Goodness of fit \\
\hline $\begin{array}{l}\text { LA } 1 \\
\text { LA } 2 \\
\text { LA } 3 \\
\text { LA } 4 \\
\text { LA } 5 \\
\text { LA } 6\end{array}$ & $\begin{array}{l}0.836 \\
0.800 \\
0.761 \\
0.738 \\
0.747 \\
0.701\end{array}$ & $\begin{array}{l}\text { C: } 0.934 \\
\text { E: } 5.310 \\
\text { V: } 33.187\end{array}$ & \multirow{3}{*}{$\begin{array}{l}\mathrm{KMO}= \\
0.943 \\
\text { Bartlett } \\
\text { test } \\
\text { Chi }= \\
3094.745 \\
\mathrm{df}=120 \\
\mathrm{p}=0.000\end{array}$} & $\begin{array}{l}0.817 \\
0.794 \\
0.844 \\
0.872 \\
0.832 \\
0.811\end{array}$ & 0.698 & $\begin{array}{l}13.849^{\text {**** }} \\
13.205^{\text {**** }} \\
14.498^{\text {*** }} \\
15.204^{\text {*** }} \\
16.801^{\text {*** }} \\
-\end{array}$ & \multirow{3}{*}{$\begin{array}{l}\text { Chi=101.348 } \\
d f=57 \\
P=0.000 \\
Q=1.778 \\
\text { GFI }=0.935 \\
\text { AGFI }=0.896 \\
\text { CFI }=0.981 \\
\text { RMSEA }= \\
0.060\end{array}$} \\
\hline $\begin{array}{l}\text { LA10 } \\
\text { LA11 }\end{array}$ & $\begin{array}{l}0.885 \\
0.758\end{array}$ & $\begin{array}{l}\text { C: } 0.865 \\
\text { E: } 2.376 \\
\text { V: } 14.849\end{array}$ & & $\begin{array}{l}0.806 \\
0.954\end{array}$ & 0.780 & $\begin{array}{l}13.535^{* * *} \\
-\end{array}$ & \\
\hline $\begin{array}{l}\text { LA12 } \\
\text { LA13 } \\
\text { LA14 } \\
\text { LA15 } \\
\text { LA16 }\end{array}$ & $\begin{array}{l}0.695 \\
0.670 \\
0.760 \\
0.813 \\
0.780\end{array}$ & $\begin{array}{l}\text { C: } 0.916 \\
\text { E: } 4.294 \\
\text { V: } 26.835\end{array}$ & & $\begin{array}{l}0.831 \\
0.865 \\
0.802 \\
0.863 \\
0.786\end{array}$ & 0.689 & $\begin{array}{l}13.642^{\text {*** }} \\
14.385^{\text {**** }} \\
13.029^{\text {*** }} \\
14.338^{\text {*** }} \\
-\end{array}$ & \\
\hline
\end{tabular}

Notes) C: Cronbach's alpha, E: eigenvalue, V: percentage of variance; ***: $p<0.01$ 
Table 4: Reliability and validity for the endogenous variables of environmental collaboration and performance

\begin{tabular}{|c|c|c|c|c|c|c|c|}
\hline \multirow[b]{2}{*}{ Items } & \multicolumn{3}{|c|}{ EFA results } & \multicolumn{4}{|c|}{ CFA results } \\
\hline & $\begin{array}{l}\text { Factor } \\
\text { loading }\end{array}$ & $\begin{array}{l}\text { Reliability } \\
\text { \& validity }\end{array}$ & $\begin{array}{l}\text { Bartlett \& } \\
\text { KMO }\end{array}$ & $\begin{array}{l}\text { Factor } \\
\text { loading }\end{array}$ & AVE & C.R. & Goodness of fit \\
\hline $\begin{array}{l}\text { GC } 1 \\
\text { GC } 2 \\
\text { GC } 3 \\
\text { GC } 4 \\
\text { GC } 4 \\
\text { GC } 6\end{array}$ & $\begin{array}{l}0.768 \\
0.767 \\
0.722 \\
0.696 \\
0.765 \\
0.650\end{array}$ & $\begin{array}{l}C: 0.926 \\
\text { E: } 5.533 \\
V: 25.150\end{array}$ & \multirow{4}{*}{$\begin{array}{l}\text { KMO: } \\
0.947 \\
\text { Bartlett } \\
\text { test } \\
\text { Chi }= \\
4872.946 \\
\mathrm{df}=231 \\
\mathrm{p}=0.000\end{array}$} & $\begin{array}{l}0.777 \\
0.811 \\
0.774 \\
0.805 \\
0.862 \\
0.848\end{array}$ & 0.662 & $\begin{array}{l}13.932^{\text {**** }} \\
15.023^{\text {**** }} \\
13.980^{\text {**** }} \\
14.800^{\text {*** }} \\
16.634^{\text {*** }} \\
-\end{array}$ & \multirow{4}{*}{$\begin{array}{l}\text { Chi=226.147 } \\
\mathrm{df}=142 \\
\mathrm{P}=0.000 \\
\mathrm{Q}=1.593 \\
\mathrm{GFI}=0.911 \\
\mathrm{AGFI}=0.868 \\
\mathrm{CFI}=0.980 \\
\text { RMSEA }= \\
0.052\end{array}$} \\
\hline $\begin{array}{l}\text { GC } 8 \\
\text { GC } 9 \\
\text { GC10 } \\
\text { GC11 }\end{array}$ & $\begin{array}{l}0.601 \\
0.605 \\
0.686 \\
0.732\end{array}$ & $\begin{array}{l}\text { C: } 0.938 \\
\text { E: } 3.124 \\
\text { V: } 14.202\end{array}$ & & $\begin{array}{l}0.877 \\
0.884 \\
0.907 \\
0.887\end{array}$ & 0.790 & $\begin{array}{l}18.930^{\text {**** }} \\
19.251^{\text {**** }} \\
20.406^{\text {**** }} \\
-\end{array}$ & \\
\hline $\begin{array}{l}\text { GC13 } \\
\text { GC14 } \\
\text { GC15 } \\
\text { GC16 }\end{array}$ & $\begin{array}{l}0.628 \\
0.715 \\
0.786 \\
0.657\end{array}$ & $\begin{array}{l}C: 0.923 \\
E: 3.526 \\
V: 16.026\end{array}$ & & $\begin{array}{l}0.829 \\
0.880 \\
0.910 \\
0.850\end{array}$ & 0.753 & $\begin{array}{l}15.558 \\
17.232 \\
18.334 \\
-\end{array}$ & \\
\hline $\begin{array}{l}\text { EP 1 } \\
\text { EP } 2 \\
\text { EP } 3 \\
\text { EP } 4 \\
\text { EP } 5 \\
\text { EP } 6\end{array}$ & $\begin{array}{l}0.835 \\
0.829 \\
0.832 \\
0.820 \\
0.813 \\
0.687\end{array}$ & $\begin{array}{l}\text { C: } 0.935 \\
\text { E: } 5.018 \\
\text { V: } 22.807\end{array}$ & & $\begin{array}{l}0.838 \\
0.856 \\
0.866 \\
0.856 \\
0.817 \\
0.785\end{array}$ & 0.700 & $\begin{array}{l}13.991^{\text {**** }} \\
14.364^{\text {**** }} \\
14.671^{\text {**** }} \\
14.371^{\text {**** }} \\
13.590^{\text {**** }} \\
-\end{array}$ & \\
\hline
\end{tabular}

Notes) C: Cronbach's alpha, E: eigenvalue, V: percentage of variance; ${ }^{* * *}: \mathrm{p}<0.01$ 
Table 5: Results of the correlation analysis

\begin{tabular}{|l|l|l|l|l|l|l|l|l|l|l|l|}
\hline var & ave & S.D. & com & tru & enc & sys & mec & int & sup & cus & env \\
\hline com & 5.023 & 1.441 & 1.000 & & & & & & & & \\
\hline tru & 5.058 & 1.440 & $\begin{array}{l}0.867 \\
(0.752)\end{array}$ & 1.000 & & & & & & & \\
\hline enc & 4.522 & 1.232 & $\begin{array}{l}0.606 \\
(0.367)\end{array}$ & $\begin{array}{l}0.661 \\
(0.437)\end{array}$ & 1.000 & & & & & & \\
\hline sys & 4.332 & 1.349 & $\begin{array}{l}0.534 \\
(0.281)\end{array}$ & $\begin{array}{l}0.571 \\
(0.326)\end{array}$ & $\begin{array}{l}0.766 \\
(0.587)\end{array}$ & 1.000 & & & & & \\
\hline mec & 4.400 & 1.294 & $\begin{array}{l}0.528 \\
(0.279)\end{array}$ & $\begin{array}{l}0.554 \\
(0.307)\end{array}$ & $\begin{array}{l}0.746 \\
(0.557)\end{array}$ & $\begin{array}{l}0.756 \\
(0.572)\end{array}$ & 1.000 & & & & \\
\hline int & 4.368 & 1.277 & $\begin{array}{l}0.513 \\
(0.263)\end{array}$ & $\begin{array}{l}0.547 \\
(0.299)\end{array}$ & $\begin{array}{l}0.595 \\
(0.354)\end{array}$ & $\begin{array}{l}0.653 \\
(0.426)\end{array}$ & $\begin{array}{l}0.666 \\
(0.444)\end{array}$ & 1.000 & & & \\
\hline sup & 4.352 & 1.393 & $\begin{array}{l}0.476 \\
(0.227)\end{array}$ & $\begin{array}{l}0.504 \\
(0.254)\end{array}$ & $\begin{array}{l}0.626 \\
(0.392)\end{array}$ & $\begin{array}{l}0.648 \\
(0.420)\end{array}$ & $\begin{array}{l}0.680 \\
(0.462)\end{array}$ & $\begin{array}{l}0.818 \\
(0.669)\end{array}$ & 1.000 & & \\
\hline cus & 4.330 & 1.368 & $\begin{array}{l}0.456 \\
(0.208)\end{array}$ & $\begin{array}{l}0.495 \\
(0.245)\end{array}$ & $\begin{array}{l}0.575 \\
(0.331)\end{array}$ & $\begin{array}{l}0.641 \\
(0.411)\end{array}$ & $\begin{array}{l}0.632 \\
(0.399)\end{array}$ & $\begin{array}{l}0.794 \\
(0.630)\end{array}$ & $\begin{array}{l}0.828 \\
(0.686)\end{array}$ & 1.000 & \\
\hline env & 4.440 & 1.230 & $\begin{array}{l}0.408 \\
(0.166)\end{array}$ & $\begin{array}{l}0.478 \\
(0.228)\end{array}$ & $\begin{array}{l}0.525 \\
(0.276)\end{array}$ & $\begin{array}{l}0.455 \\
(0.207)\end{array}$ & $\begin{array}{l}0.432 \\
(0.187)\end{array}$ & $\begin{array}{l}0.608 \\
(0.370)\end{array}$ & $\begin{array}{l}0.633 \\
(0.401)\end{array}$ & $\begin{array}{l}0.580 \\
(0.336)\end{array}$ & 1.000 \\
\hline
\end{tabular}

Notes) var: variables, ave: average, S.D.: standard error, com: commitment, tru: trust, enc: learning encouragement, sys: learning systems, mec: integrative mechanism, int: internal collaboration, sup: supplier collaboration, cus: customer collaboration, env: environmental performance, the number of parenthesis is square of a correlation coefficient. 
Table 6: Results of structural links

\begin{tabular}{|l|l|l|l|l|l|l|}
\hline & Path & Estimate & S.E. & C.R. & P & Results \\
\hline H.1 & culture $\rightarrow$ collaboration & 0.065 & 0.065 & 1.002 & 0.312 & rejected \\
\hline H.2 & learning $\rightarrow$ collaboration & 0.821 & 0.090 & 9.113 & 0.000 & supported \\
\hline H.3 & collaboration $\rightarrow$ performance & 0.649 & 0.061 & 10.691 & 0.000 & supported \\
\hline
\end{tabular}

Notes) Chi-square $=159.189, \mathrm{df}=72, \mathrm{p}=0.000, \mathrm{Q}=2.211, \mathrm{GFI}=0.909, \mathrm{AGFI}=0.867, \mathrm{CFI}=0.969$, RMSEA=0.075; culture: organizational culture; learning: learning capability; collaboration: environmental collaboration; performance: environmental performance 